\title{
Spatial distribution of foraging in female Antarctic fur seals Arctocephalus gazella in relation to oceanographic variables: a scale-dependent approach using geographic information systems
}

\author{
Christophe Guinet ${ }^{1, *}$, Laurent Dubroca ${ }^{1}$, Mary Anne Lea ${ }^{2}$, Simon Goldsworthy ${ }^{2}$, \\ Yves Cherel $^{1}$, Guy Duhamel ${ }^{3}$, Francesco Bonadonna ${ }^{1}$, Jean-Paul Donnay ${ }^{4}$ \\ ${ }^{1}$ Centre d'Etudes Biologiques de Chizé, Centre National de la Recherche Scientifique, 79360 Villiers en Bois, France \\ ${ }^{2}$ Antarctic Wildlife Research Unit, Zoology Department, University of Tasmania, GPO Box 252-05 Hobart, Tasmania 7001, Australia \\ ${ }^{3}$ Museum National d'Histoire Naturelle, Laboratoire d'Ichtyologie Générale et Appliquée, 43 rue Cuvier, 75231 Paris Cedex 05, France \\ ${ }^{4}$ Departement de Géomatique, Laboratoire SURFACES, Université de Liege, 7 place du 20 Aout (A1), 4000 Liege, Belgium
}

\begin{abstract}
The distribution of foraging activity for female Antarctic fur seals was investigated at Cap Noir (49 07' S, 7045' E), Kerguelen Island in February 1998. Eleven females were fitted with a satellite transmitter and time-depth recorder. The 2 data sets were combined in order to locate diving activity of the seals. The occurrence of fish in the diet of the seals was investigated by the identification of otoliths in 55 scats collected at the breeding colony during the study period. Oceanographic variables were measured simultaneously by direct sampling and satellite remote sensing. The mesopelagic fish community was sampled at 20 stations along 4 transects, where epipelagic trawls were conducted at night at $50 \mathrm{~m}$ depth. We then investigated, using geographic information systems, the relationship between the spatial distribution of diving activity of the seals and oceanographic variables (sea surface temperature, surface chlorophyll concentration, prey distribution and bathymetry) at the same spatio-temporal scale. An inverse relationship was found between the main fish species preyed on by the fur seals and those sampled in trawl nets. However, diving activity of the seals was significantly related to oceanographic conditions, forage fish distribution and distance from the colony, although these relationships changed with the spatial scale investigated. A probabilistic model was developed for the distribution of diving activity, which predicted where females should concentrate their foraging activity according to the oceanographic conditions of the year, and where breeding colonies should be located.
\end{abstract}

KEY WORDS: Antarctic fur seal · Diet · Oceanographic conditions · Foraging · Geographic Information System

Resale or republication not permitted without written consent of the publisher

\section{INTRODUCTION}

Seabird and pinniped populations breeding on subantarctic islands are major consumers of marine resources within the Southern Ocean, and consumption by seabirds and pinnipeds breeding at South Georgia, Crozet Island, Kerguelen Island, Heard Island and

*E-mail: guinet@cebc.cnrs.fr
Macquarie Island has been estimated at $\geq 15$ million tonnes $\mathrm{yr}^{-1}$ (Guinet et al. 1996). Marine resources are distributed heterogeneously in space and time and are generally related to spatial heterogeneity in physical, chemical and bathymetric features of the marine environment. Studies of the ecology of top predators at sea indicate that their distribution, abundance, and behaviour are related to oceanographic features and primary productivity, as found in seabirds (Pakhomov \& Mc- 
Quaid 1996, Bost et al. 1997, Guinet et al. 1997, Weimerskirch 1998), and marine mammals (e.g. cetaceans: Jaquet \& Whitehead 1996, Tynan 1998; and pinnipeds: Hindell et al. 1991, McConnell et al. 1992, Boyd et al. 1998, Georges et al. 2000). The spatial distribution patterns of seabirds and their prey have been studied by simultaneous observation during surveys. Most of these studies have shown that correlations between predators and prey increase with measurement scale (Schneider \& Piatt 1986, Heinemann et al. 1989, Erikstad et al. 1990, Hunt 1990, Mehlum et al. 1999, Fauchald et al. 2000). This change of correlation strength in relation to spatial scale has been interpreted as possible predator-prey interaction, with prey avoiding their predators at a small scale, while at larger scales predators are able to track their prey (Rose \& Leggett 1990). Furthermore, seabirds are generally able to roam over large areas, and are thus capable of exploiting the large scale patches of their prey (Fauchald et al. 2000). Until recently, studies of the pelagic distribution of seabirds were mainly conducted from ships over defined transects. The geographical origin, sex, age and reproductive stage of the birds and pinnipeds were generally not known (Abrams 1985, Stahl et al. 1985, Hunt et al. 1992, Pakhomov \& McQuaid 1996). Over the last 2 decades, methods have been introduced for tracking seabirds and marine mammals using satellite transmitters, providing information about at-sea distribution of individuals of known colonies and breeding status. Foraging activity at sea for these top predators has also been investigated by the use of multichannel digital loggers (Costa 1993, Weimerskirch et al. 1994, 1995) with variable sampling rates, which can record depth, light level, water temperature, swimming velocity and stomach temperature. The combination of data for activity and location, obtained simultaneously for the same individuals, can provide valuable information about the spatio-temporal distribution of foraging effort.

Satellite-based earth observation programs have provided an increasing number of time series on the spatio-temporal distribution of dynamic oceanographic variables, such as sea surface temperature (SST) and surface chlorophyll concentrations. This information is particularly valuable for the Southern Ocean, where classical oceanographic data obtained by ship surveys are limited. Furthermore, satellite sensors have repeatedly confirmed that the ocean environment is highly structured and they permit the detection of frontal zones, by using SST (Moore et al. 1997, Moore et al. 1999), as well as areas of high phytoplankton concentrations within the Kerguelen region (Metzl 2000). In this study we assess the relationship between the at-sea distribution of diving activity (i.e. foraging) of lactating Antarctic fur seals Arctocephalus gazella at Kerguelen
Island, and a broad range of oceanographic variables obtained on the same spatial and temporal scale and using Geographical Information Systems (GIS).

Antarctic fur seals give birth to a single pup between mid-November and late December, that they will rear until weaning 4 mo later. During the lactation period the major constraint on female fur seals is the requirement to commute back and forth between foraging areas at sea and the breeding colony where they nurse their pup. As central place foragers (Orians \& Pearson 1979), they must therefore find food within a range limited by their swimming ability and by the needs of the growing pup. Several studies have shown that foraging trip duration increases with travel distance (Boyd 1999, Bonadonna et al. 2000) and that the provisioning rate of the pup decreases with increasing foraging trip duration (Goldsworthy 1995, Guinet et al. 1999, 2000). The aim of this study was to investigate how the foraging activity of lactating fur seals is distributed at sea at a colony-population level, how foraging areas can be characterised by a range of oceanographic variables and how these relationships change with spatial scale.

\section{MATERIALS AND METHODS}

Study area and attached devices. The study took place during the 1997/1998 austral summer between 4 February and 11 March at Kerguelen Island. The study was conducted at a colony at Cap Noir $\left(49^{\circ} 07^{\prime} \mathrm{S}\right.$, $70^{\circ} 45^{\prime} \mathrm{E}$; Fig. 1), Iles Kerguelen, on the northeast of the Courbet Peninsula, where approximately 400 females bred that year. Females were captured using a hoop net and restrained on a board. A time-depth recorder (MK5-TDR Wildlife Computers, Redmond, WA, USA) mounted on top of a Platform Terminal Transmitter (PTT) (Telonics ST10, packaged by Sirtrack Ltd, New Zealand and linked to an Argos system) was attached to each seal. The package $(110 \times 42 \times 25 \mathrm{~mm}, 150 \mathrm{~g}$, cross-sectional area $10.5 \mathrm{~cm}^{2}$ ) was shaped to minimise drag and was attached with plastic cable ties to a nylon webbing strap $(110 \times 42 \mathrm{~mm})$ that was glued dorsally, on the midline between the scapulae of each seal, with double component araldite glue (AW 2101, Ciba Speciality Chemicals, Basel, Switzerland). Deployment dates are summarised in Table 1. Females were marked with serial numbers by bleaching the fur on their rump with peroxide hair dye (Clairol Born Blonde, Bristol-Myers Squibb Ltd., West Ryde, Australia). All the seals were recaptured after 1 foraging trip, and packages were subsequently redeployed on different individuals. We consider the distribution of diving activity for the 11 fur seal females equipped with a satellite unit and a TDR to be representative of the dis- 
Fig. 1. Spatial distribution of the diving activity of 11 female Antarctic fur seals from the Cap Noir colony $(*)$, Kerguelen Island, Feb 1998. Greyscale: time (h) spent diving in each $0.1^{\circ} \times 0.1^{\circ}$ square. (o) locations of trawl stations

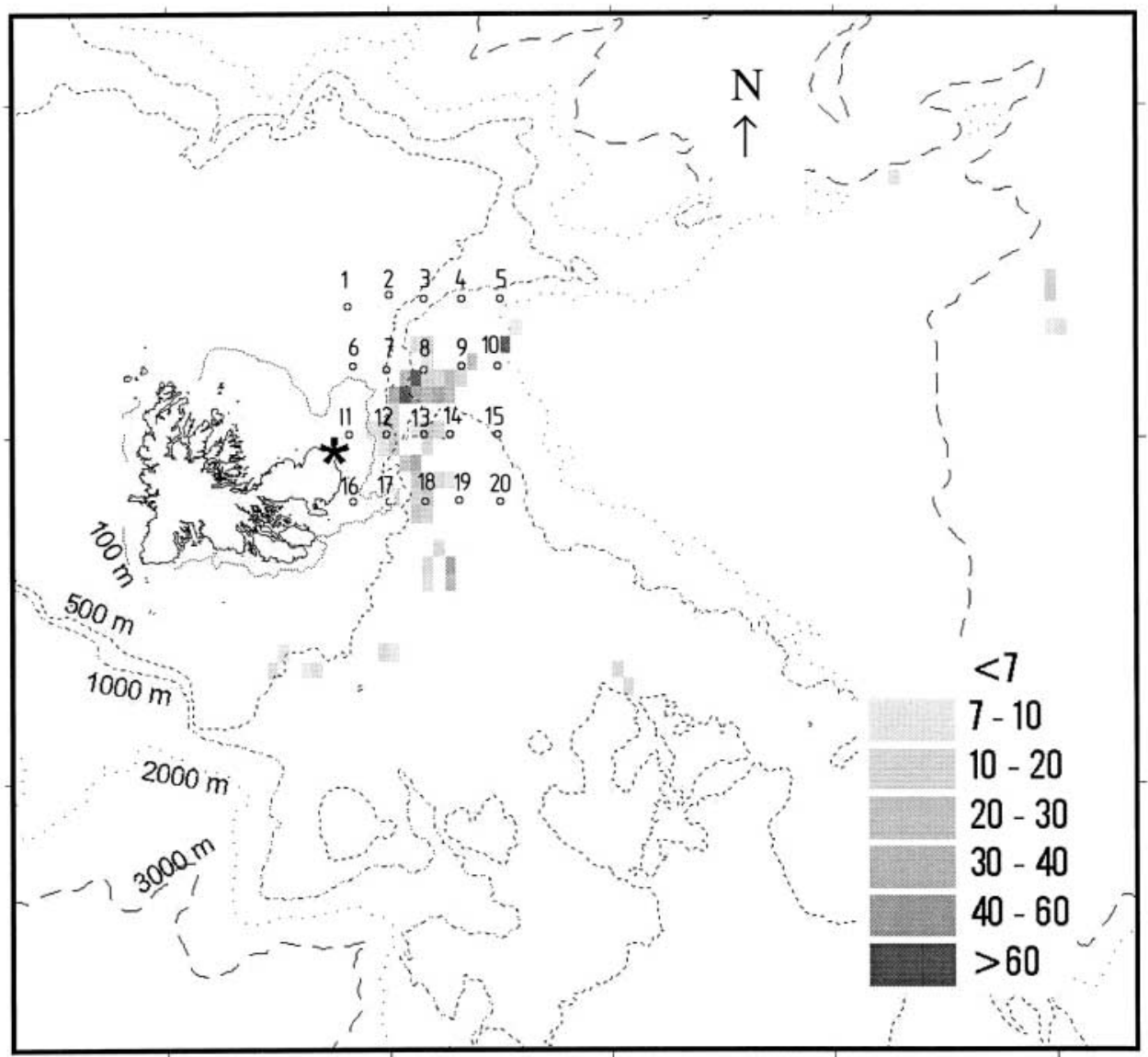

Mean' (3M) software (Wildlife Computers) to calculate dive profiles (date, time, duration, depth).

Locations were calculated by reference to 3 satellites and assigned by Argos to 6 classes on the basis of their accuracy. The accuracy of locations provided by Argos al. 1997). Fish otoliths and bones were examined by collecting 55 scats from the breeding colony where seals were captured. These scats were assumed to be representative of lactating Antarctic fur seals at Cap Noir during the study period. Individual scats were kept separately and frozen at $-20^{\circ} \mathrm{C}$ for subsequent analysis. Fish otoliths were carefully extracted, and species were determined by using the descriptions in Iwami (1985), Williams \& McEldowney (1990) and our own reference collection.

At-sea distribution of diving activity. MK5-TDRs were programmed to record wet and dry periods and depth $( \pm 1 \mathrm{~m})$ every $5 \mathrm{~s}$ with a pre-calibrated pressure transducer. Hexadecimal TDR files were converted into binary files using 'ZeroOffset-Correction' software (Wildlife Computers). Data were subsequently processed using 'Dive Analysis' and 'Mean-Max-

Table 1. Deployment date and foraging trip durations for the 11 seals

\begin{tabular}{|c|c|c|c|c|}
\hline Seal & $\begin{array}{c}\text { Date \& time of } \\
\text { deployment }^{\mathrm{a}}\end{array}$ & $\begin{array}{l}\text { Trip duration } \\
\text { (d) }\end{array}$ & $\begin{array}{c}\text { Maximum }^{\mathrm{b}} \\
\text { distance }(\mathrm{km})\end{array}$ & $\begin{array}{c}\text { Route }^{\mathrm{c}} \\
\text { distance }(\mathrm{km})\end{array}$ \\
\hline B & 05 Feb 15:35 & 7.2 & 98 & 404 \\
\hline $\mathrm{C}$ & 05 Feb 16:20 & 5.7 & 97 & 279 \\
\hline $\mathrm{G}$ & 05 Feb 17:14 & 8 & 152 & 472 \\
\hline $\mathrm{H}$ & 05 Feb 18:00 & 2.9 & 88 & 192 \\
\hline M & 11 Feb 18:51 & 17 & 547 & 1500 \\
\hline $\mathrm{D}$ & 12 Feb 16:03 & 5 & 111 & 276 \\
\hline L & 14 Feb 12:00 & 7.9 & 243 & 525 \\
\hline $\mathrm{N}$ & 15 Feb 17:25 & 3.8 & 68 & 206 \\
\hline I & 18 Feb 11:05 & 6.7 & 118 & 281 \\
\hline $\mathrm{E}$ & 19 Feb 18:15 & 6.9 & 145 & 365 \\
\hline F & 25 Feb 12:32 & 5.9 & 93 & 191 \\
\hline \multicolumn{2}{|c|}{$\bar{x} \pm \mathrm{SD}$} & $7 \pm 3.7$ & $160 \pm 136.8$ & $426.4 \pm 373.2$ \\
\hline \multicolumn{5}{|c|}{$\begin{array}{l}{ }^{a} \text { Local time at which device was attached } \\
{ }^{\mathrm{b}} \text { Max distance from the colony reached by a seal during a foraging trip } \\
{ }^{\mathrm{c}} \text { Total horizontal length of foraging trip }\end{array}$} \\
\hline
\end{tabular}


is classified as follows: class 3 is accurate to $150 \mathrm{~m}$, class 2 to $350 \mathrm{~m}$, class 1 to $1 \mathrm{~km}$, and classes $0, \mathrm{~A}$, and $\mathrm{B}$ have no accuracy assigned. The error associated with the location of the devices by the Argos system can be estimated by considering location of females known to be at the colony. Only the 4 most accurate classes $(0,1,2,3)$ were then included in these analyses (Boyd et al. 1998, Bonadonna et al. 2000). Argos data were plotted using Elsa97 software (release 1.1, Soft \& Technique Informatique, Toulouse, France). Locations were filtered such that those that suggested transit speeds $>3 \mathrm{~m} \mathrm{~s}^{-1}$ were discarded (see Jouventin et al. 1994, Weimerskirch et al. 1995, Bost et al. 1997, Bonadonna et al. 2000).

Spatial distribution of diving activity. For each seal, at-sea location data were combined with diving activity data according to their common time basis. Relative use of oceanic sectors was calculated and plotted using Weavers' (1992) hypothesis. Fur seal females were assumed to move in a straight line between 2 locations. Furthermore, it was assumed that while diving there was no horizontal displacement. Between 2 locations the number of dives, their duration and their exact timing were determined. The cumulative dive time $\left(t_{\mathrm{d}}, \mathrm{s}\right)$ was then retrieved from the total time $\left(t_{\mathrm{T}}, \mathrm{s}\right)$ between the 2 locations, and the average travelling speed was then calculated according to the distance, $D$, separating the 2 locations:

$$
V=D /\left(t_{\mathrm{T}}-t_{\mathrm{d}}\right), \quad \text { in } \mathrm{m} \mathrm{s}^{-1}
$$

The location of the first dive was determined according to the time elapsed since the previous location using the above calculation for travelling speed. This procedure was repeated for subsequent inter-dive periods until the following satellite location. Custom-made software ${ }^{1}$ was then used to estimate the amount of time spent diving in each $0.1^{\circ} \times 0.1^{\circ}(11.1 \mathrm{~km}$ lat. $\times 7.3 \mathrm{~km}$ long. $)$ area of a grid encompassing the whole study area.

Environmental data. Bathymetric data were extracted from the ETOPO database, with a resolution of $5^{\prime} \times 5^{\prime}$, using the SeaDAS software. A bathymetric gradient layer was then created, as several studies have shown that Antarctic fur seals forage on the outer limits of peri-insular plateaus, e.g. Heard Island (Green 1997), South Georgia (Boyd et al. 1998) and Kerguelen (Bonadonna et al. 2000). Satellite SST and [chlorophyll] data were extracted for February 1998, consistent with the deployment date of the satellite tags (see Table 1). SST data at $9 \mathrm{~km}$ resolution were obtained from the NOAA/NASA AVHRR Ocean Pathfinder Program (Smith et al. 1996, http://podaac.jpl.nasa.gov/sst/) and read by the SeaDAS software. SST gradients maps

${ }^{1}$ Dive Location Software can be provided by LD on request were also calculated from these data as an indicator of the major frontal structures in the area (Moore et al. 1997, 1999). Surface chlorophyll concentrations at the same resolution measured by SeaWIFS were provided by NOAA/NASA (http://daac.gsfc.nasa.gov/). Gradients were defined for each of the environmental variables by calculating the maximum slope around each pixel from the local slopes in $x$ and $y$. Only neighbours above, below and to either side of the pixel are accounted for in this 'rook's case' procedure. The algorithm (IDRISI Module Surface Analysis) computes percent slope for each pixel using the 'tangent' trigonometric function. As fur seal females are central place foragers during the lactation period we decided to take into account the distance separating the colony from the node of each grid cell, by calculating the orthodromic distance from the colony.

Diet and prey distribution. Female Antarctic fur seals at Iles Kerguelen dive almost exclusively at night, within the first $100 \mathrm{~m}$ depth (unpubl. data). Myctophids, which represented the main part of the diet of female Antarctic fur seals at Ile Nuageuses, to the north-west of Iles Kerguelen (Cherel et al. 1997), undertake diel vertical migrations and are close to the surface at night and in deeper waters during the day. The fish were sampled by pelagic trawl, from the $25 \mathrm{~m}$ reseach vessel 'La Curieuse', of the Institut Français pour la Recherche et la Technologie Polaires (IFRTP). The sampling was conducted exclusively at night, between 21:00 and 04:00 $\mathrm{h}$ local time at a standard depth of $50 \mathrm{~m}$, chosen according to diving behaviour monitored during the first $2 \mathrm{wk}$ of the study using time depth recorders (M.-A. Lea, S. Goldsworthy, C. Guinet unpubl. data). An International Young Gadoid Pelagic Trawl (IYGPT) was used, with an opening of $12 \times 7 \mathrm{~m}$ and a $10 \mathrm{~mm}$ mesh size in the codend (Duhamel et al. 2000). Depth of fishing was checked with a depth sensor (Scanmar AS, Norway) clipped on the net. The net was deployed for a standard $30 \mathrm{~min}$ of trawling, with a constant speed of 3 knots, according to Duhamel et al. (2000). The sampling was conducted between 16 and 21 Feb 1998, along 4 zonal transects separated by $0.40^{\circ}$ latitude, over the area $48.20^{\circ} \mathrm{S}, 70.80^{\circ} \mathrm{E} /$ $49.40^{\circ} \mathrm{S}, 72.00^{\circ} \mathrm{E}$. Each transect contained 5 stations separated by $\sim 0.30^{\circ}$ longitude (Fig. 1). We distinguished 2 groups of fish: (1) the overall number of fish sampled, and (2) the number of forage fish of fur seals (i.e. those representing more than $2 \%$ of the total number of otoliths found in the fur seal scats). The results obtained for each station in terms of total number of fish sampled and total number of forage fish were interpolated at $0.1^{\circ} \times 0.1^{\circ}$ scale, over the sampled area using the INTERPOL procedure of the IDRISI software (i.e. the weighted mean of the 12 closest neighbouring pixels). Data were interpolated using a 
digital elevation model by means of a distanceweighted average. A distance weight exponent of 2 was chosen, yielding a weight equal to the reciprocal of the squared distance. We also conducted the same analysis considering only the number of forage fish at each of the 20 stations and the amount of time the seal spent diving in the corresponding zone, at scales of $0.1^{\circ} \times 0.1^{\circ}, 0.2 \times 0.2^{\circ}$ and $0.3^{\circ} \times 0.3^{\circ}$, centred on the corresponding trawling station. It was not possible to conduct this investigation at greater scale, as the areas in which the amount of time spent diving was calculated, centred on each trawling station, started to overlap with each other. Larval and pre-juvenile fish specimens were not considered in this study as at this stage, even from a shoal, they are of negligible energetic value for the top marine predators (see Duhamel et al. 2000).

Spatial scale and Geographic Information Systems. The extent of the study area corresponded to a circle centred on the study colony, with a radius of the maximum theoretical foraging range of the lactating Antarctic females, estimated to be $650 \mathrm{~km}$. This corresponded with the maximum distance travelled by a lactating female equipped with a PTT in this study. This defined a study area of 16454 discrete grid squares at a $0.1^{\circ} \times$ $0.1^{\circ}$ scale. Within that study area we assumed that each pixel could be visited by female fur seals. In this study, we assumed that the seals knew from past experience which areas were suitable and accessible foraging habitat. We thus considered that non-use of a habitat was as informative as its use, and thus grid cells that fur seals did not dive in were still included in the analysis. This is consistent with the findings of Bonadonna et al. (2000), which showed that female fur seals travelled directly to their foraging ground, where they then concentrated their searching, without stopping on the Kerguelen Plateau. In this study the accessibility of an area was taken into account by including the distance of a grid cell from the colony.

All data sets were transformed to the same scale grid $\left(0.1^{\circ} \times 0.1^{\circ}\right)$ using a plate square projection and the spatial analyst module of the Arcview ${ }^{\circledR}$ GIS software. The value of each pixel was attributed according to the projected point. Satellite SST and chlorophyll values were missing due to cloud cover for $1.6 \%$ and $3.2 \%$ of the pixels respectively. Missing values in pixels were attributed by interpolation (see above). The data were then transformed to raster data and analysed using the IDRISI GIS ${ }^{\circledR}$ software. The resulting GIS databases included data on 7 independent biophysical variables stored in raster format. Relationships between the environmental variables and the at-sea distribution of diving activity of fur seals were investigated using multi-linear regression analysis between the environmental data and the level of div- ing activity for each $0.1^{\circ} \times 0.1^{\circ}$ geo-referenced pixel. We also applied the multilinear regression to surface trends models at a $0.1^{\circ} \times 0.1^{\circ}$ geographical scale. This method takes into account the spatial change in environmental variables (Unwin 1975). The method is called 'trend surface analysis' because the basic model used attempts to decompose each observation on a spatially distributed variable into a component associated with purely local effects. This separation into 2 components is accomplished by fitting a best-fit surface of a previously specified type using standard regression techniques. The values predicted by this trend-surface are assigned to the regional effects whereas the local departures of the observed data from it, or residuals, are assigned to the local effects (Unwin 1975). For a given environmental variable, data sets were found to be spatially auto-correlated at a small geographical scale. We thus applied a Bonferroni correction and results were considered to be significant at $p \leq 0.005$. The influence of scale on these relationships was investigated by aggregating pixels from a scale ranging from $0.1^{\circ} \times 0.1^{\circ}$ to $3^{\circ} \times 3^{\circ}$ with an increment of $0.1^{\circ}$ between each scale investigated. Figures with maps were compiled with Arcview ${ }^{\circledR}$ GIS software.

\section{RESULTS}

\section{Spatial distribution of diving activity}

Deployment dates and durations of foraging trips are summarised in Table 1. Lactating fur seals at Cap Noir, Iles Kerguelen, concentrated their foraging activity on the northeast outside edge of the Kerguelen Plateau, in waters deeper than $500 \mathrm{~m}$, with nearly no diving taking place in shallower waters. Most fur seals concentrated their foraging activity in an area at the edge of the Kerguelen Plateau nearest to the colony; however, 1 fur seal travelled $547 \mathrm{~km}$ east of the colony to truly oceanic waters (Fig. 1). The trawl stations used encompassed the main fur seal foraging areas (Fig. 1).

\section{Diet and fish sampled}

A total of 25 species of fish were identified according to otoliths obtained from fur seal scats (Table 2). The main prey species were 2 species of myctophids: Gymnoscopelus piabilis (29.1\% by number), Electrona subaspera (17.1\%) and 1 channichtyid, Champsocephalus gunnari $(10.2 \%)$. Juvenile and adult specimens of 18 fish species were sampled by trawl net for the 20 sampling stations, 10 species of which were preyed on by fur seals (Table 3). We found a negative relationship between the number of otoliths per fish species found 
Table 2. Frequency of occurrence and numbers of otoliths of species of fishes in 55 scats of fur seals from Cap Noir, Kerguelen Islands

\begin{tabular}{|c|c|c|c|c|}
\hline \multirow[t]{2}{*}{ Species } & \multicolumn{2}{|c|}{ Occurrence } & \multicolumn{2}{|c|}{ Numbers } \\
\hline & $\mathrm{n}$ & $\%$ & & $\%$ \\
\hline \multicolumn{5}{|l|}{ Microstomatidae } \\
\hline ?Nansenia antarctica & 3 & 5.5 & 7 & 0.4 \\
\hline \multicolumn{5}{|l|}{ Notosudidae } \\
\hline Scopelosaurus hamiltoni & 5 & 9.1 & 7 & 0.4 \\
\hline \multicolumn{5}{|l|}{ Paralepididae } \\
\hline Paralepididae sp. & 1 & 1.8 & 1 & $<0.1$ \\
\hline \multicolumn{5}{|l|}{ Myctophidae } \\
\hline Electrona antarctica & 10 & 18.2 & 19 & 1.2 \\
\hline Electrona carlsbergi & 4 & 7.3 & 26 & 1.6 \\
\hline Electrona subaspera & 35 & 63.6 & 269 & 17.1 \\
\hline Gymnoscopelus bolini & 1 & 1.8 & 2 & 0.1 \\
\hline Gymnoscopelus braueri & 1 & 1.8 & 1 & $<0.1$ \\
\hline Gymnoscopelus nicholsi & 19 & 34.5 & 152 & 9.6 \\
\hline Gymnoscopelus fraseri & 17 & 30.9 & 61 & 3.9 \\
\hline Gymnoscopelus piabilis & 39 & 70.9 & 461 & 29.2 \\
\hline Gymnoscopelus sp. (eroded) & 25 & 45.5 & 131 & 8.3 \\
\hline Krefftichthys anderssoni & 11 & 20 & 24 & 1.5 \\
\hline Metelectrona ventralis & 6 & 10.9 & 11 & 0.7 \\
\hline Protomyctophum andriashevi & 1 & 1.8 & 1 & $<0.1$ \\
\hline Protomyctophum bolini & 18 & 32.7 & 46 & 2.9 \\
\hline Protomyctophum choriodon & 13 & 23.6 & 39 & 2.5 \\
\hline Protomyctophum tenisoni & 7 & 12.7 & 9 & 0.6 \\
\hline Myctophidae sp. (eroded) & 23 & 41.8 & 97 & 6.2 \\
\hline \multicolumn{5}{|l|}{ Muraenolepididae } \\
\hline Muraenolepis marmoratus & 1 & 1.8 & 2 & 0.1 \\
\hline \multicolumn{5}{|l|}{ Zoarcidae } \\
\hline Melanostigma gelatinosum & 1 & 1.8 & 2 & 0.1 \\
\hline \multicolumn{5}{|l|}{ Nototheniidae } \\
\hline Gobionotothen acuta & 1 & 1.8 & 4 & 0.3 \\
\hline Notothenia cyanobrancha & 1 & 1.8 & 1 & $<0.1$ \\
\hline \multicolumn{5}{|l|}{ Harpagiferidae } \\
\hline Harpagifer spinosus ${ }^{\mathrm{a}}$ & 6 & 10.9 & 23 & 1.5 \\
\hline \multicolumn{5}{|l|}{ Channichthyidae } \\
\hline Champsocephalus gunnari & 13 & 23.6 & 161 & 10.2 \\
\hline \multicolumn{5}{|l|}{ Gempylidae } \\
\hline Paradiplospinus gracilis & 3 & 5.5 & 3 & 0.2 \\
\hline \multicolumn{5}{|l|}{ Centrolophidae } \\
\hline Icichthys australis & 5 & 9.1 & 10 & 0.6 \\
\hline Eroded otoliths & 5 & 9.1 & 7 & 0.4 \\
\hline Total & - & - & 1577 & 100.0 \\
\hline
\end{tabular}

in the fur seal scats (Table 2) and the numerical abundance of these species sampled in trawl nets $\left(\mathrm{r}_{\mathrm{s}}=-0.74\right.$, $\mathrm{n}=10, \mathrm{p}=0.02$ ) and no $C$. gunnari were sampled, despite the fact that they represented a large proportion $(10.2 \%)$ of the fur seal diet during that period.

\section{Environmental variables}

Oceanographic data for bathymetry, SST and nearsurface chlorophyll concentration are presented in
Table 3. Frequency of occurrence and numbers of fish caught in trawl nets at 20 stations. Only species accounting for $>0.5 \%$ of total fish shown in the group of the minor fur seal prey

\begin{tabular}{|c|c|c|c|c|}
\hline \multirow{2}{*}{ Species } & \multicolumn{2}{|c|}{ Occurrence } & \multicolumn{2}{|c|}{ Numbers } \\
\hline & $\mathrm{n}$ & $\%$ & & $\%$ \\
\hline \multicolumn{5}{|l|}{ Major fur seal prey $(>2 \%)$} \\
\hline \multicolumn{5}{|l|}{ Myctophidae } \\
\hline Electrona subaspera & 9 & 45 & 32 & 0.6 \\
\hline Gymnoscopelus fraseri & 5 & 25 & 134 & 2.5 \\
\hline Gymnoscopelus nicholsi & 9 & 45 & 133 & 2.5 \\
\hline Gymnoscopelus piabilis & 3 & 15 & 5 & 0.1 \\
\hline Protomyctophum bolini & 9 & 45 & 809 & 14.9 \\
\hline Protomyctophum choriodon & 6 & 30 & 11 & 0.1 \\
\hline \multicolumn{5}{|l|}{ Minor fur seal prey $(<2 \%)$} \\
\hline \multicolumn{5}{|l|}{ Myctophidae } \\
\hline Electrona antarctica & 9 & 45 & 1316 & 24.2 \\
\hline Gymnoscopelus braueri & 5 & 25 & 238 & 4.3 \\
\hline Krefftichthys anderssoni & 6 & 30 & 1083 & 19.9 \\
\hline Protomyctophum tenisoni & 11 & 55 & 1623 & 29.9 \\
\hline Other species $(\mathrm{n}=8)$ & 12 & 60 & 54 & 1.0 \\
\hline Total & & & 5438 & 100.0 \\
\hline
\end{tabular}

Fig. 2. In February 1998, SST data exhibit a marked temperature gradient associated with the subantarcticsubtropical fronts north of Kerguelen Island and with the Antarctic Polar Front south and east of Kerguelen Island. The surface chlorophyll data indicate that there were high chlorophyll concentrations to the north-east of Kerguelen Island during the study period. The chlorophyll gradient indicates that areas with highly contrasted levels also occur to the north-east but also south-east of the archipelago. Among all the fish species sampled we distinguished 6 prey species caught in trawl nets and representing more than $2 \%$ of the otoliths found in fur seal scats in February 1998 (Table 3). The numerical variations in overall fish sampled and fish prey abundance throughout the trawled area are given in Fig. 3. The interpolated distributions of fish for all species sampled and for the main fish prey species are presented in Fig. 4. The main fish prey species were only sampled in waters deeper than $500 \mathrm{~m}$ (Fig. 4).

\section{Relationship between the spatial distribution of fur seal diving activity and environmental variables}

The results for the multi-linear regression analysis between the amount of time spent diving by fur seals during a foraging trip (DIVE, $\mathrm{h}$ ) in a $0.1^{\circ} \times 0.1^{\circ} \mathrm{grid}$ and the 7 associated environmental variables: distance from the colony (DIS, km), bathymetry (BAT, m), bathymetric gradient (BATg, \%), chlorophyll concentration $\left(\mathrm{CHL}, \mathrm{mg} \mathrm{m}^{-3}\right.$ ), chlorophyll gradient $(\mathrm{CHLg}, \%)$, sea surface temperature $\left(\mathrm{SST},{ }^{\circ} \mathrm{C}\right)$ and sea surface temperature gradient (SSTg, \%)-are presented in Fig. 5 

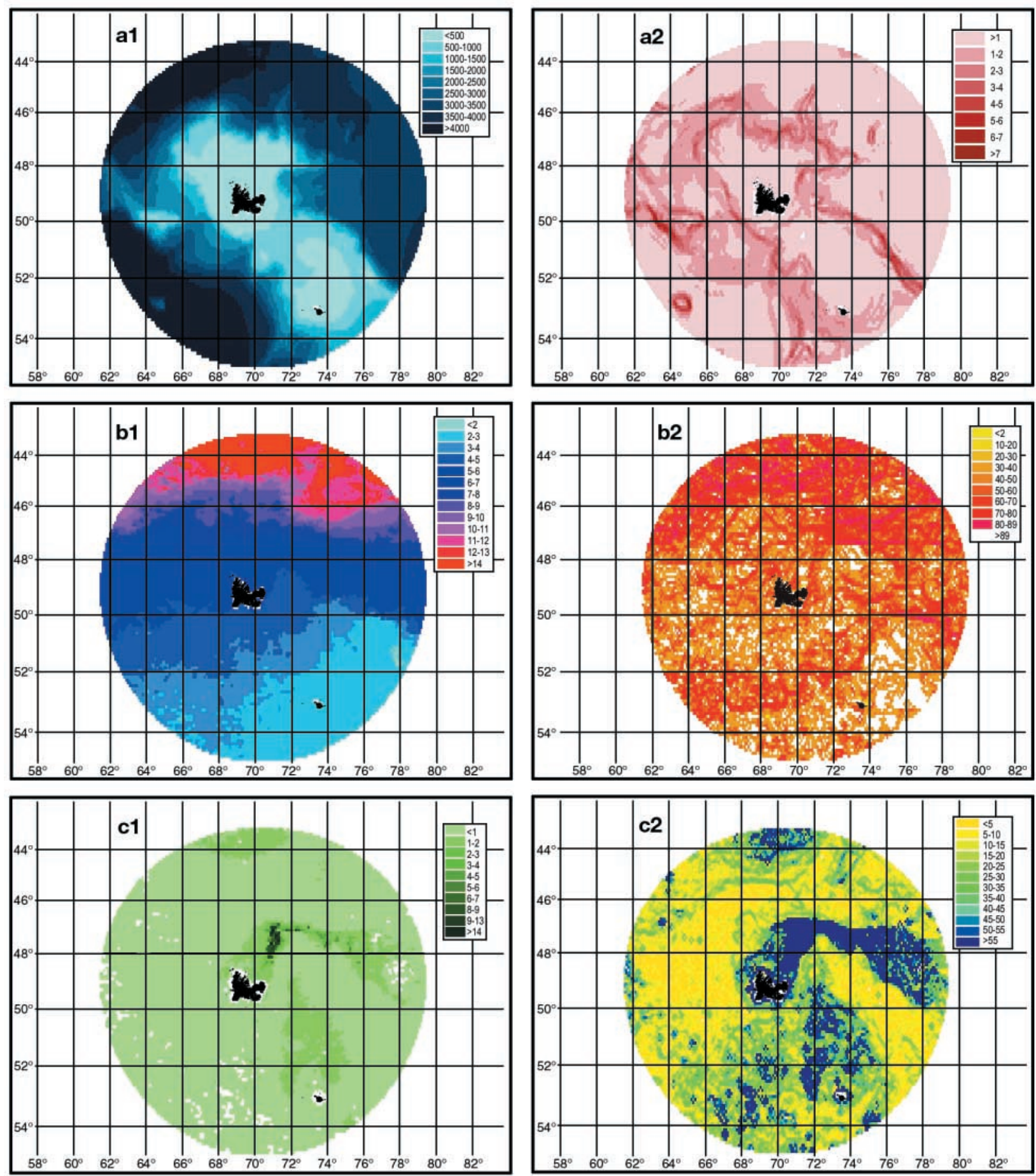

Fig. 2. Mapping of oceanographic conditions at $0.1^{\circ} \times 0.1^{\circ}$ scale within $650 \mathrm{~km}$ maximum foraging radius of Cap Noir colony:

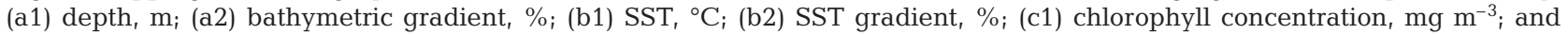
(c2) chlorophyll concentration gradient, \%. Dynamic variables (b1, b2, c1, c2) averaged for Feb 1998

for grid sizes ranging from $0.1^{\circ} \times 0.1^{\circ}$ to $3^{\circ} \times 3^{\circ}$ and a sample size (grid numbers) ranging from 16454 to 13 . The coefficient of determination tended to increase with spatial scale; however, due to the decrease in grid numbers with increasing spatial scale, significant rela- tionships were mainly found at scales of $0.1^{\circ} \times 0.1^{\circ}$ to $1^{\circ} \times 1^{\circ}$ and $1.8^{\circ} \times 1.8^{\circ}$ to $2.2^{\circ} \times 2.2^{\circ}$ (Fig. 5a). Five environmental variables (DIS, BAT, BATg, CHL, CHLg) were found to have a significant effect on the amount of time spent diving in a given grid. However, as 


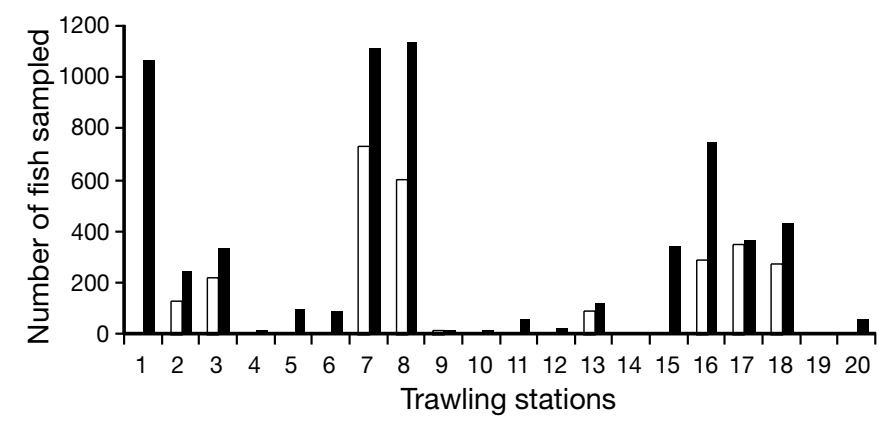

Fig. 3. Number of fish sampled for each of the trawling stations: black, total fish; white, forage fish (i.e. 6 main prey species) and in 13 of the stations when only the main fish prey species were considered (Fig. 3). The distribution of the diving activity of fur seals was found to match the spatial distribution of their main fish prey (Fig. 6). The results of the multi-linear regression between DIVE and environmental variables within the main area sampled for fish prey are summarised in Table 5. The amount of time spent diving in a grid cell was positively related to the main fish prey abundance (FISH), BAT, and BATg, and negatively related to DIS. When considering only the number of fish sampled for forage fish at each of the 20 stations, we found that the amount of time spent diving was not correlated to the number of fish sampled at shown in Fig. 5, for a given variable, the relationship changed according to the grid scale used. The distance from the colony was negatively related to the amount of time spent diving in a given location. The amount of time spent diving in a grid was positively related to BAT, BATg and CHLg at smaller grid scales $\left(0.1^{\circ}\right.$ to $0.3^{\circ}$ grid scale), negatively related to $\mathrm{CHL}$ at a small grid scale but positively related to $\mathrm{CHL}$ at a larger grid scale (Fig. 5). Only $2 \%$ of the total variance in the amount of time spent diving in an area was accounted for by the environmental variables at a scale of $0.1^{\circ} \times 0.1^{\circ}\left(\mathrm{r}^{2}=0.02, \mathrm{n}=16454, \mathrm{p}\right.$ $<0.001$, Fig. 5a); this increased to $44 \%$ at a scale of $2^{\circ} \times 2^{\circ}\left(r^{2}=0.44, n=27, p<0.001\right.$, Fig. $5 a)$. The relationship was greatly improved by using a multi-linear regression on surface trend models applied to environmental variables for a scale of $0.1^{\circ} \times 0.1^{\circ}$. All variables (DIVE, BAT, BATg, CHL, CHLg, SST, SSTg) except distance from colony (DIS) were fitted by a cubic polynomial trend surface model. The fits were all significant at $p=0.025$. By using this model all the environmental variables investigated were found to have a significant effect on the amount of time spent diving in an area, and this model accounted for $96 \%$ of the total variance in DIVE per grid area. Diving activity was negatively related to DIS, CHLg, and SST, but positively related to BAT, BATg, CHL and SSTg (Table 4).

The relationship between DIVE and all the oceanographic variables previously used as well as forage fish abundance was investigated for the area sampled by trawl nets at a $0.1^{\circ} \times$ $0.1^{\circ}$ scale (Fig. 6). Numbers of forage fish in grid cells not sampled were estimated by interpolation. Fish were present at the 20 stations when all species sampled were considered,
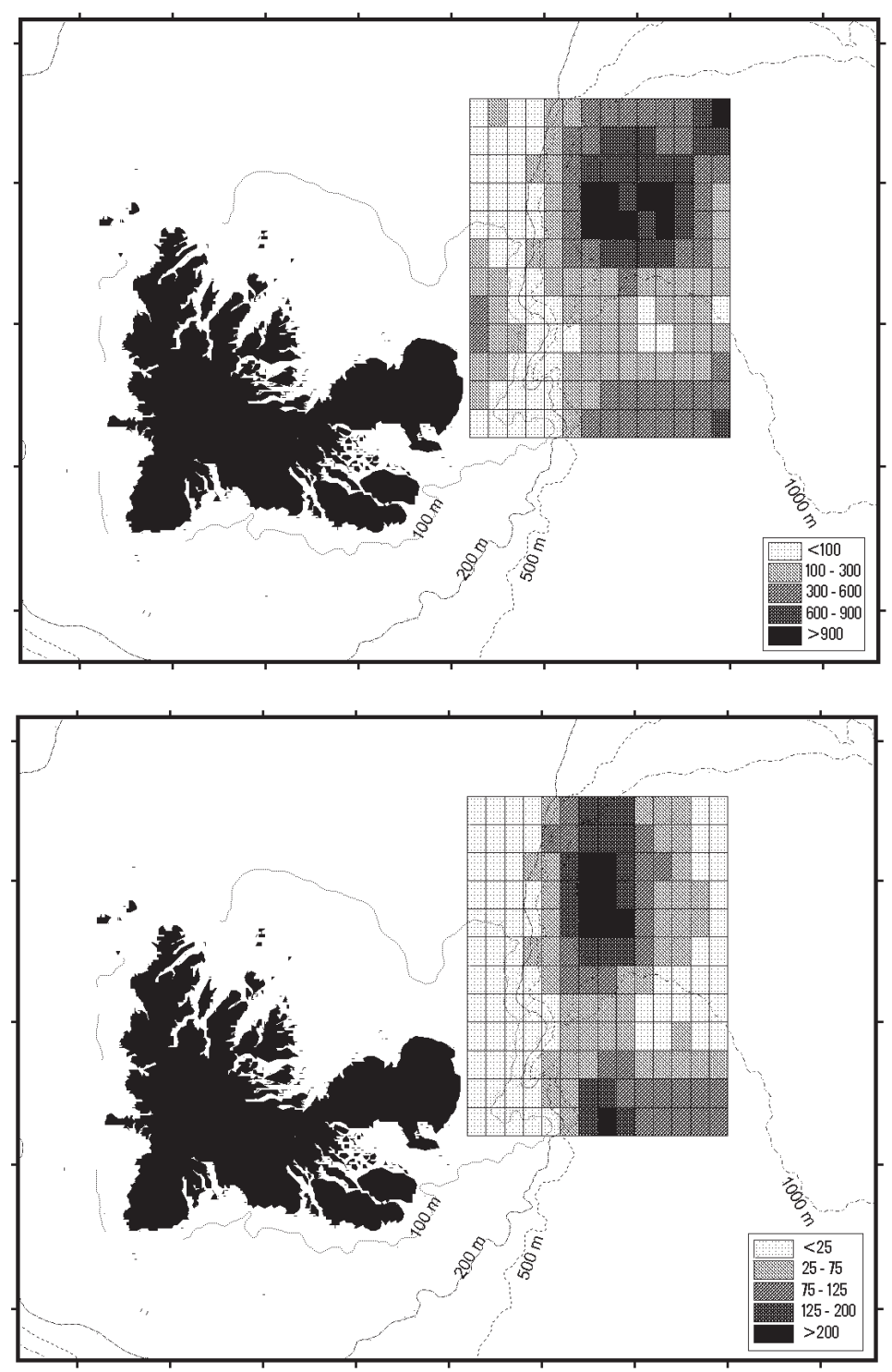

Fig. 4. Interpolations for: (a) total fish, and (b) forage fish, over fish sampling area $\left(48.10^{\circ} \mathrm{S}, 70.70^{\circ} \mathrm{E}\right.$ to $\left.49.40^{\circ} \mathrm{S}, 72.00^{\circ} \mathrm{E}\right)$ from $16-21$ Feb 1998. Greyscale shows estimated number of fish per trawl 

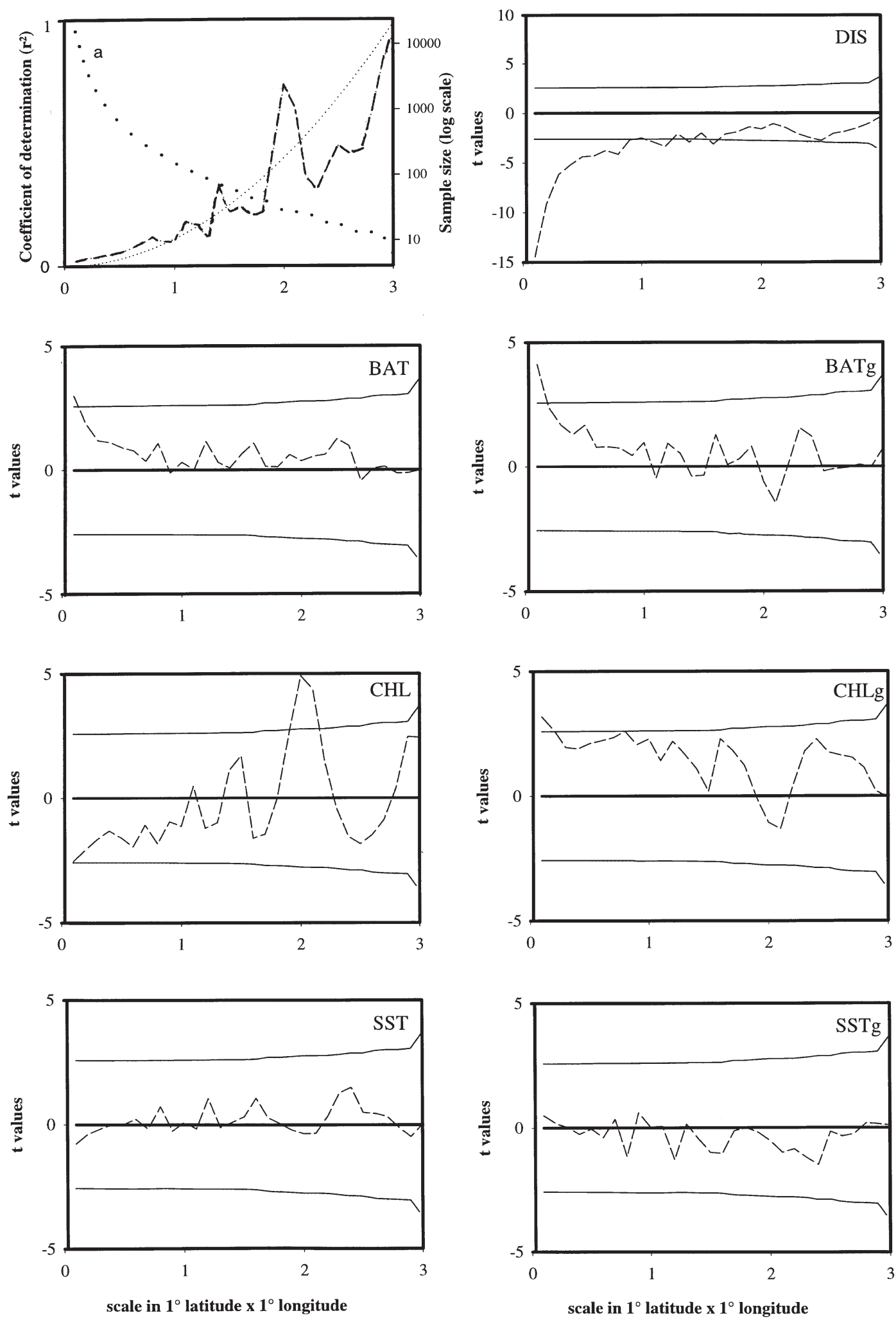

Fig. 5. Results of multi-linear regression (dashed lines) for time spent diving (h) and environmental variables at spatial scales of $0.1^{\circ} \times 0.1^{\circ}$ to $3^{\circ} \times 3^{\circ}$. (a) Overall model; (DIS) distance from colony; (BAT) bathymetry; (BATg) bathymetric gradient; (CHL) surface chlorophyll concentration; (CHLg) surface chlorophyll concentration gradient; (SST) sea surface temperature; (SSTg) sea surface temperature gradient. In (a), bold dotted line $(. \cdots$.$) ) indicates change in sample size (16454 to 13, log scale) in relation to increasing$ spatial scale, fine dotted line (.....) indicates minimum significant $\mathrm{r}^{2}$ at $\mathrm{p}<0.005$; in the other panels, fine lines $(\longrightarrow)$ indicate minimum significant $t$-value at $\mathrm{p}<0.005$ 
Table 4. Relationship between amount of time spent diving $\left(0.1^{\circ} \times 0.1^{\circ}\right.$ cells $)$ and corresponding environmental variables using a multi-linear regression analysis on surface trend models

\begin{tabular}{|ll|}
\hline $\begin{array}{l}\text { Regression statistic } \\
\mathrm{R}^{2}=0.96\end{array}$ & $\begin{array}{l}F(7,16447)=64794 \\
\mathrm{p}<0.001 \\
t \text {-values }\end{array}$ \\
Variables & 13.79 \\
\hline BAT & 18.87 \\
BATg & 83.92 \\
CHL & -40.51 \\
SHLg & -108.05 \\
SSTg & -70.93 \\
DIS & -25.68 \\
\hline
\end{tabular}

a scale of $0.1^{\circ} \times 0.1^{\circ}\left(\mathrm{r}_{\mathrm{s}}=3.63, \mathrm{n}=20, \mathrm{p}=0.11\right)$ but a positive correlation was found at a scale of $0.2^{\circ} \times 0.2^{\circ}\left(\mathrm{r}_{\mathrm{s}}=\right.$ $0.492, \mathrm{n}=20, \mathrm{p}=0.05)$ and at a scale of $0.3^{\circ} \times 0.3^{\circ}\left(\mathrm{r}_{\mathrm{s}}=\right.$ $0.540, \mathrm{n}=20, \mathrm{p}=0.02$ ).

\section{DISCUSSION}

This study shows that in February 1998 lactating Antarctic fur seals were mostly foraging within $150 \mathrm{~km}$ of the colony, although one female travelled up to $547 \mathrm{~km}$ east. The foraging activity of these females was generally concentrated over an area east of Cap Noir, characterised by particular oceanographic conditions as well as the distance from the colony, a critical factor for central place foragers. The relationships between
Table 5. Multi-linear regression for amount of time spent diving and corresponding environmental variables, including fish prey abundance. Analysis for $0.1^{\circ} \times 0.1^{\circ}$ cells where fish were sampled (Fig. 5). ${ }^{*}$ Significant at $p<0.001$

\begin{tabular}{|ll|}
\hline Regression statistic & \\
$\mathrm{R}^{2}=0.38$ & $\begin{array}{l}F(8,159)=11.80 \\
\mathrm{p}<0.001 \\
\text { Variables }\end{array}$ \\
\hline BAT & $3.13^{*}$ \\
BATg & $3.93^{*}$ \\
CHL & 1.63 \\
CHLg & -0.96 \\
SST & -1.62 \\
SSTg & 1.11 \\
DIS & $-5.46^{*}$ \\
FISH & $3.40^{*}$ \\
\hline
\end{tabular}

the spatial distribution of diving activity with oceanographic parameters were also found to be scale-dependent. The values of the coefficient of determination tended to increase with spatial scale (i.e. the proportion of the variance accounted for). However, related to the concomitant decrease in sample size with spatial scale, relationships were only significant at a small and medium spatial scale (Fig. 5a). Positive relationships between the amount of time spent diving, and bathymetry, bathymetric gradient and chlorophyll gradient, were found at a small geographical scale. Fur seals were found to dive in deep waters associated with strong bathymetric and chlorophyll gradients that occur near to the breeding colony. For all these variables the

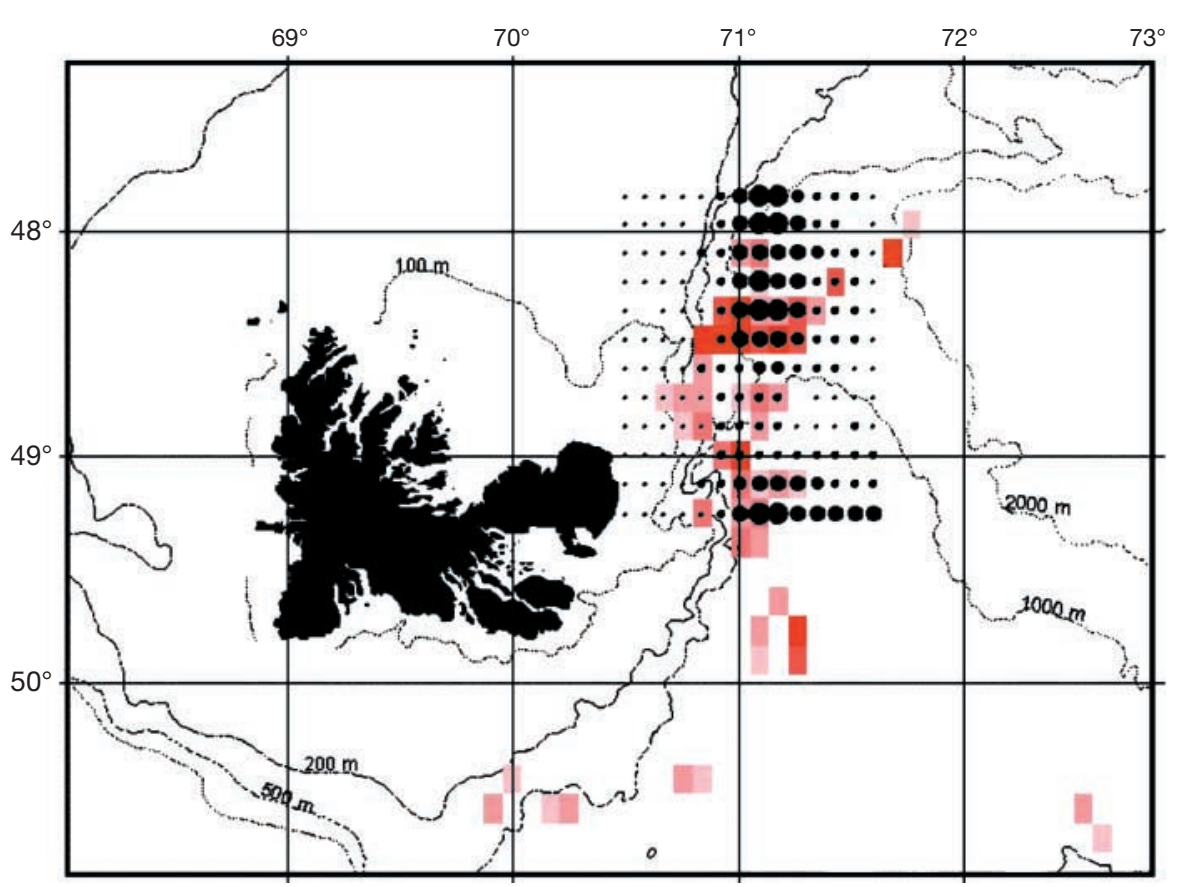

Interpolated number of fish by trawl (main prey

Time sent diving species) (h/seal)

$$
\begin{array}{ll} 
& 0-25 \\
\text { - } & 25-75 \\
\text { - } & 75-125 \\
\text { - } & 125-200 \\
\text { l } & >200
\end{array}
$$

Fig. 6. Overlay over the fish sampled area at $0.1^{\circ} \times 0.1^{\circ}$ scale of the spatial distribution of the amount of time spent diving by 11 female Antarctic fur seals from the Cap Noir colony, Kerguelen Island, indicated by the red-scales with the interpolated fish prey $(>2 \%$ of otolith numbers) abundance in numbers indicated by increasing size black circles 
strength of the correlation decreased with increasing scale, suggesting that fur seals were responding to small-scale change in these features. With increasing scale the definition of these small-scale features decreased while the spatial distribution of the diving activity is spread over large unused areas resulting in a likely decrease in the strength of the correlation. The diving activity of fur seals tended to be negatively related to near-surface chlorophyll concentration at a small spatial scale but was positively related at a larger scale. The increase with spatial scale in correlation strength between the diving effort of female Antarctic fur seals, chlorophyll concentration and the main fish prey is coherent with most studies conducted to date exploring predator-chlorophyll or predator-prey interaction in relation to the spatial scale, which have found that the strength of correlation between seabirds and their prey abundance increase at larger scales (Schneider \& Piatt 1986, Heinemann et al. 1989, Erikstad et al. 1990, Obst \& Hunt 1990, Jacquet \& Whitehead 1996). However, we found a decrease in the strength of the relationship between the spatial distribution of and the other oceanographic variables investigated. The change in the significance of oceanographic variables according to the spatial-scale used suggests that the importance of such features to the foraging patterns of marine predators is scale-dependent, that is, the scale at which one oceanographic variable is important to the foraging patterns of predators may differ from the scale at which a different variable is important.

As the data about foraging activity were obtained over the whole month of February 1998, we decided to use environmental variables such as SST or chlorophyll concentrations and their gradient data collected and averaged over the whole month of February 1998; by doing this we expected a change in spatial pattern to occur within the study period. Small spatial scale structures probably change faster than the large spatial scale structure within the time frame of our study. As a consequence, by working over a monthly time period, the small-scale changes are likely to remain undetected. However, these data provide the larger spatial scale pattern of the oceanographic conditions over the study period. Thus, small-scale relationships between these environmental variables and the amount of time spent diving in an area are likely to remain undetected. Any relationships are more likely to be found at a broader scale. Conversely, we can expect a correlation at a smaller scale between the spatial distribution of diving activity, bathymetry and the bathymetric gradient, which do not change with time.

Oceanographic studies have also shown that there is generally a spatial de-correlation between the distribution of chlorophyll and the distribution of secondary and tertiary production (Vinogradov 1981). This de- correlation can be explained by the time-lag between primary, secondary and tertiary production. Peaks in chlorophyll concentration may thus be temporally and spatially separated from peaks in secondary production due to the drift associated with currents (Jacques 1988, Lévy 1996). The positive relationship we found at a larger scale indicates that fur seal females tend to forage within large areas characterised by high primary production despite the absence of a positive relationship at a smaller scale. This is supported by the results obtained with the surface trend analysis, indicating that fur seals tend to forage within areas of higher chlorophyll concentration.

The methodology used in this study may also account for some of the differences. Most of the studies investigating the relationship between marine predators and their prey were studies conducted from sightings of individuals from unknown colonies and of unknown breeding status, in which all sightings were taken into account regardless of their foraging status. In our study we only investigated these relationships in areas where individually tracked fur seals were foraging. Furthermore, in several studies (Schneider \& Piatt 1986, Heinemann et al. 1989, Erikstad et al. 1990, Obst \& Hunt 1990) the relationships between marine predators and their prey were investigated at a smaller spatial scale (of the order of nautical miles), and in some of these studies (Mehlum et al. 1999) the largest spatial scales investigated were within the lower range of the spatial scale used in our study, $0.1^{\circ} \times 0.1^{\circ}$.

Using the statistical relationships that we found by multi-linear regression, we are able to project onto a map the most favourable foraging grounds, according to oceanographic conditions and the location of breeding colonies. This model may be a useful tool for predicting the most favourable foraging habitats based on average oceanographic conditions nearest to Iles Kerguelen, and the coastal areas in nearest proximity to these that are likely to be the most favourable sites for breeding colonies. According to these statistical relationships and by not taking into account the distance from the colony we located the favourable foraging zone of fur seals off Iles Kerguelen according to the environmental conditions observed in February 1998 (Fig. 7).

At a $0.1^{\circ} \times 0.1^{\circ}$ scale, multi-linear regression models accounted for only $2 \%$ of the total variance of the model, but this proportion increased with increasing scale (Fig 5a). The proportion of variance accounted for increased to $96 \%$ when using a surface trend regression model. Such large differences between multilinear and surface trend regression models can be explained by the conceptual differences between these 2 approaches. The multi-linear regression approach examined the correlation between the variables. In a 

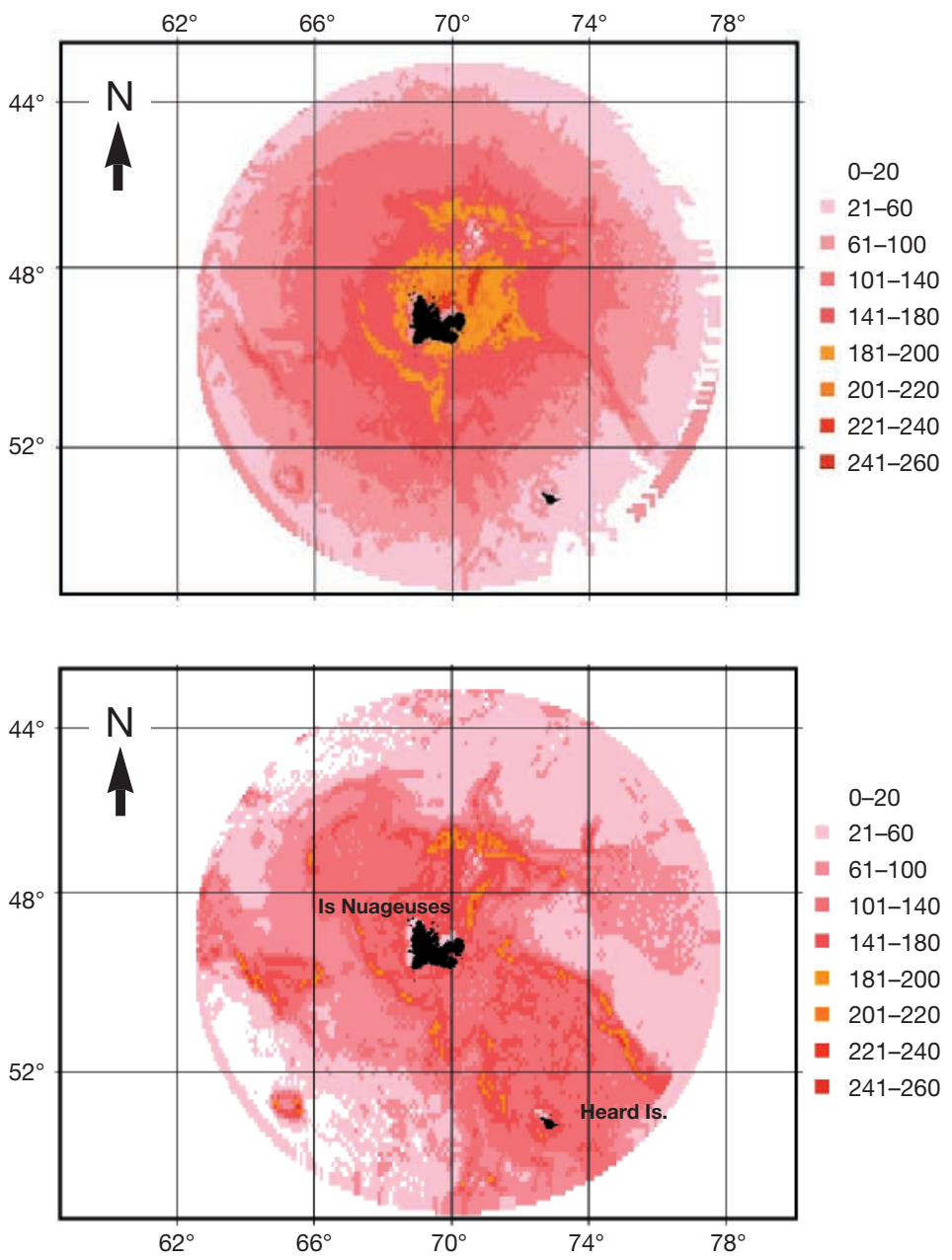

Fig. 7. Predicted spatial distribution of time spent diving (h) at $0.1^{\circ} \times 0.1^{\circ}$ scale, using multi-linear regression model, when distance from colony (a) included, and (b) excluded

surface trend regression analysis, where data are adjusted by polynomial models, correlations are investigated between spatial trends (i.e. regional components) of the variables, overlooking the local variability of the environmental data used. Thus, the results obtained through a surface trend analysis indicate that $96 \%$ of the variance in the spatial distribution of diving activity is accounted for by the regional trends found within the explanatory variables. It is interesting that while we found no significant effect of sea-surface temperature or sea surface temperature gradient with the multi-linear regression model at any scale, the amount of time spent diving was positively related to the spatial/regional trend of SST gradient and negatively related to the spatial/regional trend of SST using a surface trend regression model. This result suggests that female fur seals tended to forage in colder water within an area of high SST gradient, i.e. in the vicinity of the Polar Front. Furthermore, trends in chlorophyll concentration had a strong positive effect in the regional component of their at-sea distribution.

Within the trawl survey area, diving activity was correlated with the interpolated abundance of the main fish prey, the bathymetry, the bathymetric gradient and the distance from the breeding colony. The main fish prey abundance was also correlated to overall fish abundance and these results strongly suggest that fur seals concentrated their diving activity in areas of high fish abundance. The spatial distribution of the abundance of fish in our study results from the interpolation of data collected at only 20 stations, and this interpolation can be problematic when prey is patchily distributed. Furthermore, fish abundance was estimated over 168 grid cells while the original data were obtained from only 20 stations. For all these reasons, the relationship we found between the distribution of foraging activity and interpolated fish prey abundance should be interpreted with caution. However, when considering only the results obtained for the 20 trawl stations, we found an increased correlation between the number of forage fish sampled and the amount of time spent diving. In addition, the distribution of forage fish obtained before and after the interpolation of the data is consistent with present knowledge of the biogeography of these fish. The myctophid species (Electrona subaspera, Gymnoscopelus piabilis, G. nicholsi, Protomyctophum choriodon) preyed on by female fur seals (Table 1) are known to inhabit the slope area (Hulley et al. 1989) while the benthopelagic channichthyid, Champsocephalus gunnari mainly inhabits the outer shelf/upper slope area of the Kerguelen Plateau, where it feeds on swarming crustaceans and myctophids including E. subaspera, P. choriodon, P. tenisoni (Duhamel 1991, Cherel et al. 1997). This is also consistent with the spatial distribution of foraging activity of the seals. These females were mostly foraging beyond the $500 \mathrm{~m}$ depth contour and in areas with high bathymetric gradients, while none of the fish sampled over the Kerguelen plateau were part of the fur seal diet. The behavioural data collected on diving activity and swimming speed of the seals suggest that females only commence diving once they have travelled a distance consistent with the distance separating the edge of the Kerguelen Plateau from the colony at Cap Noir (Bonadonna et al. 2000). Thus, the spatial distribution of foraging activity of may be attributed to the habitat preferences of their main prey species (Duhamel 
1991). The 3 main myctophid prey species of the seals (G. piablis, E. subaspera, G. nicholsi) are known to be concentrated within the $50 \mathrm{~m}$ surface layer at night (Duhamel 1998, Duhamel et al. 2000), while G. piabilis and E. subaspera occur in waters deeper than $300 \mathrm{~m}$ during the day (Duhamel et al. 2000). During the day these main fish prey species are thus out of the diving range of the seals and this finding is consistent with their night diving behaviour (Bonadonna et al. 2000).

However, we found a negative relationship between the occurrence of forage fish and the number of individual fish sampled per species, despite the fact that trawl sampling occurred exclusively at night, within the main diving area at a depth consistent with diving behaviour, and that diving was positively correlated to the overall abundance of their main fish prey. This result suggests that either: (1) there is a bias in diet composition from scat analysis; (2) fur seals are selective in their diet; or, (3) catchability of fish species by the trawl net was biased and thus the sampled fish population was unrepresentative of their relative abundance. We should expect some bias in the diet composition estimated from scat analysis as smaller otoliths can be completely digested in comparison to those of larger individuals or species (Silva \& Neilson 1985) and smaller prey species such as $P$. bolini and $P$. choriodon may be underestimated in comparison to larger Gymnoscopelus spp. At this stage we are unable to conclude to what extent the other 2 hypotheses may influence findings but we should expect the the foraging selectivity of fur seals is likely to be based on the rate of energy intake, which is likely to be related to the behaviour and catchability of the prey (e.g. schooling, mobility) and their accessibility. Other variables such as prey size and energy content may also be important. Future work should take into account these variables in assessing prey choice within the fish community available to female fur seals.

Our study highlights the applicability of GIS in investigating the effect of spatial scale on the spatial relationships between environmental variables and marine predators. This study indicates that the at-sea distribution of foraging activity of marine predators can be closely related to environmental variables and the abundance of the forage fish, and suggests, in our case, that lactating Antarctic fur seals can be used with some confidence as indicators of the distribution of their prey. Among these environmental variables, some are static (e.g. bathymetry) while others (e.g. SST \& [chlorophyll]) are spatially and temporally dynamic. Studies conducted over continuous time, or for the same season over several years, will provide further insight into the effects of changes in oceanographic conditions on the at-sea distribution and foraging efficiency of top marine predators, such as the Antarctic fur seal.
Acknowledgements. This work was supported by the Institut Français pour la Recherche et Technologie Polaire (IRTP), by the Groupement de Recherche 'ecosystèmes polaires et anthropisation' du programme vie et société du CNRS, and by the Australian Antarctic Science Advisory Committee (ASAC grant 2128) and Sea World Research and Rescue Inc., Australia. F.B. was financed by a Marie Curie Fellowship from the European Community (Fourth Framework Programme, Training and Mobility of Researchers, contract no. ERBFMBICT972614). We particularly wish to thank A. Lamale, R. Pagny and H. Pereau for making our stay at Cap Noir very comfortable. We also wish to thank the crew of 'la Curieuse' for their permanent and friendly help during the cruise. The authors would like to thank the SeaWIFS project (code 18417) and the Distributed Active Archive Center (code 902) at the Goddard Space Flight Center, Greenbelt, MD 20771, USA, for the production and distribution of these data. We also thank $\mathrm{S}$. Chamaillet and S. Mangin who assisted with diet sorting and N. Metzl for stimulating discussions.

\section{LITERATURE CITED}

Abrams RW (1985) Environmental determinants of pelagic seabird distribution in the African sector of the southern ocean. J Biogeogr 12:473-492

Bonadonna F, Lea MA, Guinet C (2000) Foraging routes of Antarctic fur seals (Arctocephalus gazella) investigated by the concurrent use of satellite tracking and time depth recorders. Polar Biol 23:149-159

Bost CA, Georges JY, Guinet C, Cherel Y, Pütz K, Charrassin JB, Handrich Y, Zorn T, Lage J, Le Maho Y (1997) Foraging habitat and food intake of satellite-tracked king penguins during the austral summer at Crozet Archipelago. Mar Ecol Prog Ser 150:21-33

Boyd IL (1999) Foraging and provisioning in Antarctic fur seals: interannual variability in time-energy budgets. Behav Ecol 10:198-208

Boyd IL, McCaffertyDJ, Reid K, Taylor R, Walker TR (1998) Dispersal of male and female Antarctic fur seals (Arctocephalus gazella). Can J Fish Aquat Sci 55:845-852

Cherel Y, Guinet C, Tremblay Y (1997) Fish prey of Antarctic fur seals Arctocephalus gazella at Ile de Croy, Kerguelen. Polar Biol 17:87-90

Costa DP (1993) The secret life of marine mammals. Oceanography 6:120-128

Duhamel G (1991) The biological and demographic peculiarities of the icefish Champsocephalus gunnari Lönnberg, 1905 from the Kerguelen Plateau. In: Di Prisco G, Maresca B, Tota B (eds) Biology of Antarctic fishes. SpringerVerlag, Berlin, p 40-53

Duhamel G (1998) The pelagic fish community of the Polar Frontal Zone off the Kerguelen Islands. In: Di Prisco G, Pisano E, Clarke A (eds) Fishes of Antarctica: a biological overview. Springer-Verlag, Berlin, p 63-74

Duhamel G, Koubbi P, Ravier C (2000) Day and night mesopelagic fish assemblages off the Kerguelen Islands (Southern Ocean). Polar Biol 23:106-112

Erikstad KE, Moun T, Vader W (1990) Correlations between pelagic distribution of common and Brünnich's guillemenots and their prey in the Barents Sea. Polar Res 8:77-87

Fauchald P, Erikstad KE, Skarsfjord H (2000) Scale-dependent predator-prey interactions: the hierarchical spatial distribution of seabirds and prey. Ecology 81:773-783

Georges JY, Bonadonna F, Guinet C (2000) Foraging habitat and diving activity of lactating subantarctic fur seals in relation to sea surface temperature at Amsterdam Island. Mar Ecol Prog Ser 196:291-304 
Goldsworthy SD (1995) Differential expenditure of maternal resources in Antarctic fur seals, Arctocephalus gazella, at Heard Island, southern Indian Ocean. Behav Ecol 6: 218-228

Green K (1997) diving behaviour of Antarctic fur seals Arctocephallus gazella Peters around Heard Island. In: Hindell MA, Kemper C (eds) Marine mammal research in the southern hemisphere, Vol 1: status, ecology and medicine. Surrey Beatty \& Sons, Chipping Norton, p 97-104

Guinet C, Cherel Y, Ridoux V, Jouventin P (1996) Consumption of marine resources by seabirds and seals in Crozet and Kerguelen waters: changes in relation to consumer biomass 1962-1985. Antarct Sci 8:23-30

Guinet C, Koudil M, Bost CA, Durbec JP, Georges JY, Mouchot MC, Jouventin P (1997) Foraging behavior of satellite-tracked king penguins in relation to sea-surface temperatures obtained by satellite telemetry at Crozet Archipelago, a study during three austral summers. Mar Ecol Prog Ser 150:11-20

Guinet C, Goldsworthy S, Robinson S (1999) Sex differences in mass loss rate and growth efficiency in Antarctic fur seal (Arctocephalus gazella) pups at Macquarie Island. Behav Ecol Sociobiol 46:157-163

Guinet C, Lea MA, Goldsworthy SD (2000) Mass change in Antarctic fur seal (Arctocephalus gazella) pups in relation to maternal characterisitics at iles Kerguelen. Can J Zool 78:476-483

Heinemann D, Hunt GL, Everson I (1989). Relationships between the distributions of marine avian predators and their prey, Euphausia superba, in Bransfield Strait and southern Drake Passage, Antarctica. Mar Ecol Prog Ser $58: 3-16$

Hindell MA, Burton HR, Slip DJ (1991) Foraging areas of southern elephant seals, Mirounga leonina, as inferred from water temperature data. Aust J Mar Freshw Res 42: 115-128

Hulley PA, Camus P, Duhamel G (1989) Ichthyological results of cruise MD-42/SIBEX-II. Part 1. Fishes from RMT-8 stations, with additional records of lanternfishes (Myctophydae: Osteichthyes) from the Indian and Atlantic sector of the Southern Ocean. Cybium 13:83-99

Hunt GL (1990) The pelagic distribution of marine birds in an heterogenous environment. Polar Res 8:43-54

Hunt GL, Heinemann D, Everson I (1992) Distributions and predator-prey interactions of macaroni penguins, Antarctic fur seals, and Antarctic krill near Bird Island, South Georgia. Mar Ecol Prog Ser 86:15-30

Iwami T (1985) Osteology and relationships of the family Channichthydae. Mem Natl Inst Polar Res E 36:1-69

Jacques G (1988) Flux de carbone en milieu pélagique de méditerranée occidentale lors de la floraison printanière. Oceanol Acta, $\mathrm{n}^{\circ}$ special: 143-148

Jaquet N, Whitehead H (1996) Scale dependent correlation of sperm whale distribution with environmental features and productivity in the South Pacific. Mar Ecol Prog Ser 153:1-9

Jouventin P, Capdeville D, Cuenot-Chaillet F, Boiteau C (1994) Exploitation of pelagic resources by a non-flying seabird: satellite tracking of the king penguin throughout the breeding cycle. Mar Ecol Prog Ser 106:11-19

Levy M (1996) Modèlisation des processus biogéochimiques en méditerrannée nord-occidentale. Cycle saisonnier et variabilité mésoéchelle. Thèse de Doctorat, Université Paris IV

McConnell BJ, Chambers C, Fedak MA (1992) Foraging ecology of southern elepehant seals in relation to the bathymetry and productivity of the Southern Ocean. Antarct Sci 4:393-398
Mehlum F, Hunt GL, Klusek Z, Decker MB (1999) Scaledependent correlations between the abundance of Brünnich's guillemots and their prey. J Anim Ecol 68:60-72

Metzl N (2000) Le programme OISO, Service d'Observation de l'Océan Indien. Lettre IGBP/PMRC/France, N10, Fev 2000

Moore JK, Abbott MR, Richman JG (1997) Variability in the location of the Antarctic Polar Front $\left(90^{\circ}-20^{\circ} \mathrm{W}\right)$ from satellite sea surface temperature data. J Geophys Res 102: $825-833$

Moore JK, Abbott MR, Richman JG (1999) Location and dynamics of the Antarctic Polar Front from satellite sea surface temperature data. J Geophys Res 104:3059-3073

Obst BS, Hunt GL (1990) Marine birds feed at gray whale mud plumes in the Bering Sea. Auk 107:678-688

Orians GH, Pearson NE (17979) On the theory of central place foraging. In: Horn DJ, Stairs GR, Mitchell RD (eds) Analysis of ecological systems. Ohio State University Press, Columbus, p 155-177

Pakhomov EA, McQuaid CD (1996) Distribution of surface zooplankton and seabirds across the Southern Ocean. Polar Biol 16:271-286

Rose GA, Legget WC (1990) The importance of scale to predator-prey spatial correlations: an example of Atlantic fishes. Ecology 71:33-43

Schneider DC, Piatt JF (1986) Scale dependent correlation of seabirds with schooling fish in a coastal ecosystem. Mar Ecol Prog Ser 32:237-246

Silva J, Neilson JD (1985) Limitation of using otoliths recovered in scats to estimate prey consumption in seals. Can J Fish Aquat Sci 42:1439-1442

Smith E, Vazquez J, Tran A, Sumagaysay R (1996) Satellitederived sea surface temperature data available from the NOAA/NASA Pathfinder program http://www.agu.org/eos _elec/95274e.html @ 1996 American Geophysical Union

Stahl JC, Jouventin P, Mougin JL, Roux JP, Weimerskirch H (1985) The foraging zones of seabirds in the Crozet Islands sector of the Southern Ocean. In: Siegfried WR, Condy R, Laws RM (eds) Antarctic nutrient cycles and food webs. Springer-Verlag, Berlin, p 478-486

Tynan CT (1998) Ecological importance of the southern boundary of the Antarctic Circumpolar Current. Nature 392:708-710

Uwin D (1975) An introduction to trend surface analysis. Concepts and Techniques in Modern Geography 5:1-40

Vinogradov ME (1981) Ecosystems of equatorial upwellings. In: Longhurst AR (ed) Analysis of marine ecosystems. Academic Press, London, p 69-94

Weavers BW (1992) Seasonal foraging ranges and travels at sea of little penguins Eudyptula minor, determined by radiotracking. Emu 91:302-307

Weimerskirch H (1998) Foraging strategies of Indian Ocean albatrosses and their relationship with fisheries. In: Robertson G, Gales R (eds) Albatross: biology and conservation. Surrey Beatty \& Sons, Chipping Norton, p 168-179

Weimerskirch H, Doncaster CP, Cuenot-Chaillet F (1994) Pelagic seabirds and the marine environment: foraging patterns of wandering albatrosses in relation to prey availability and distribution. Proc R Soc Lond B 255:91-97

Weimerskirch H, Wison RP, Guinet C, Koudil M (1995) The use of seabirds to monitor sea-surface temperatures and to validate satellite remote-sensing measurements in the Southern Ocean. Mar Ecol Prog Ser 126:299-303

Williams R, McEldowney A (1990) A guide to the fish otoliths from waters off the Australian Antarctic Territory, Heard and Macquarie Islands. ANARE Res Notes 75:1-173 